\title{
CSR Communication Model in Facing Industry Revolution 4.0
}

\author{
Susi Andrini ${ }^{1}$, Poppy Ruliana ${ }^{2}$, Suhendra Atmaja ${ }^{3}$, Irwansyah ${ }^{4}$, Riyanto ${ }^{5}$ \\ Renty Yuniarti ${ }^{6}$ \\ ${ }^{1}$ Program Studi Ilmu Komunikasi, (STIKOM) InterStudi, Indonesia \\ ${ }^{2}$ Program Pasca Sarjana Ilmu Komunikasi, (STIKOM) InterStudi, Indonesia \\ ${ }^{3}$ SKK MIGAS, Indonesia \\ ${ }^{4}$ Universitas Indonesia, Indonesia \\ ${ }^{5}$ Program Studi Ilmu Komunikasi, (STIKOM) InterStudi \\ ${ }^{6}$ Indonesia Program Studi Ilmu Komunikasi, (STIKOM) InterStudi, Indonesia \\ Corresponding Author's Email : ussie69@gmail.com
}

\begin{abstract}
Abstrak. The CSR-Indonesian Awards event held by MePRindo is faced with the problem of how CSR communication models deal with the industrial revolution 4.0. The purpose of this research is to find out and find CSR communication models in facing the 4.0 industrial revolution. The method used is descriptive with a qualitative approach. Data obtained through observation and in-depth interviews and observations of informants (Managing Director \& Chief Executive, MePRindo) as a counterweight to the information that researchers took three informants representing CSR Awards participants. The concept used in this study uses the communication model Anne Ellreup Nielsen and Crista Thomson, while the concept of CSR uses the opinion of Archi B. Carrol and the concept of the industrial revolution uplifts the opinion of Klaus Martin Schwab. Data analysis is performed through data reduction, data presentation, verification, and conclusions. The results showed that the CSR communication model in the face of the industrial revolution 4.0 played a major role in the successful implementation of CSR Awards conducted by MePRindo.
\end{abstract}

Keywords: communication model, CSR, industrial revolution, social media, award

\section{INTRODUCTION}

The world is undergoing a changing era, starting from companies that are developing or advancing, ready or not ready to be faced in the era of digitalization in the use of technology in the era of the industrial revolution 4.0. The issue of science and technology cannot be dammed in such a way and will continue to flow globally in this part of the world. Both for developed and developing countries even underdeveloped even though the progress of science and technology can penetrate the boundaries of both the real world and cyberspace (internet). Several advanced companies have also utilized this digital media in implementing CSR. With the digital era and the 4.0 Industrial revolution, any news that can be entered 
in just seconds. In contrast to the past before people knew the internet or digital media, conventional media such as electronic media, such as television and radio and print media, such as newspapers and magazines, had different influences in the world of information (Ruliana and Marlinda, 2016)

In addition, more and more companies are recognizing image and reputation risks and opportunities from implementing corporate social responsibility (CSR) programs and companies aligning corporate behavior with the expectations of stakeholders is a sustainable business priority. However, communication often remains a missing link in corporate CSR practices, this is crucial as companies are faced with the industrial revolution 4.0. Fauzan (2018) argues that the characteristics of Industry 4.0 are a combination of technological developments such as physical cyberspace, information and communication technology, communication networks, big data / cloud computing, modeling, virtualization, simulations and tools developed to facilitate human interaction with computers that can be used a tool or channel to communicate the implementation of the CSR Award.

Information requirements of various opinion leaders and audiences as stakeholders are currently not met by many companies, so they do not get a good response as a result of company behavior. (Nayan Mitra, Asif Akhtar and Ananda Das Gupta (2018) Of course, there are special challenges in communicating corporate responsibility - including skepticism about company messages and possible adverse reactions from the media and others. Diverse information requirements from various groups stakeholders also present special communication challenges, but what must be noted by companies is that the success of CSR programs in a company is largely determined by the selection of the right issues in the focus of its activities and sustainability, the selection of these issues needs to consider a number of data, or take the issues which is often discussed, then adapts it to the needs of the stakeholders. (Ruliana and Marlinda 2016)

The media can help communicate all CSR programs carried out by the company and it is the company's obligation to set aside profits for CSR activities, is MEPRINDO (Indigenous Indonesian Media) as a forum that helps companies to promote CSR activities that have been carried out by companies through the CSR Award event. The CSR-Indonesia Awards event has been running for 3 years starting from Jakarta (2017), Bandung (2018) and Bali (2019). The irony is when more and more companies are doing CSR, but many of those companies haven't done it. This is reinforced by Sherif H. Tehemar's research results which have shown that despite the increasing importance of CSR communication, organizations must still learn how to communicate their CSR. (in the India csr,webpage 2012). 

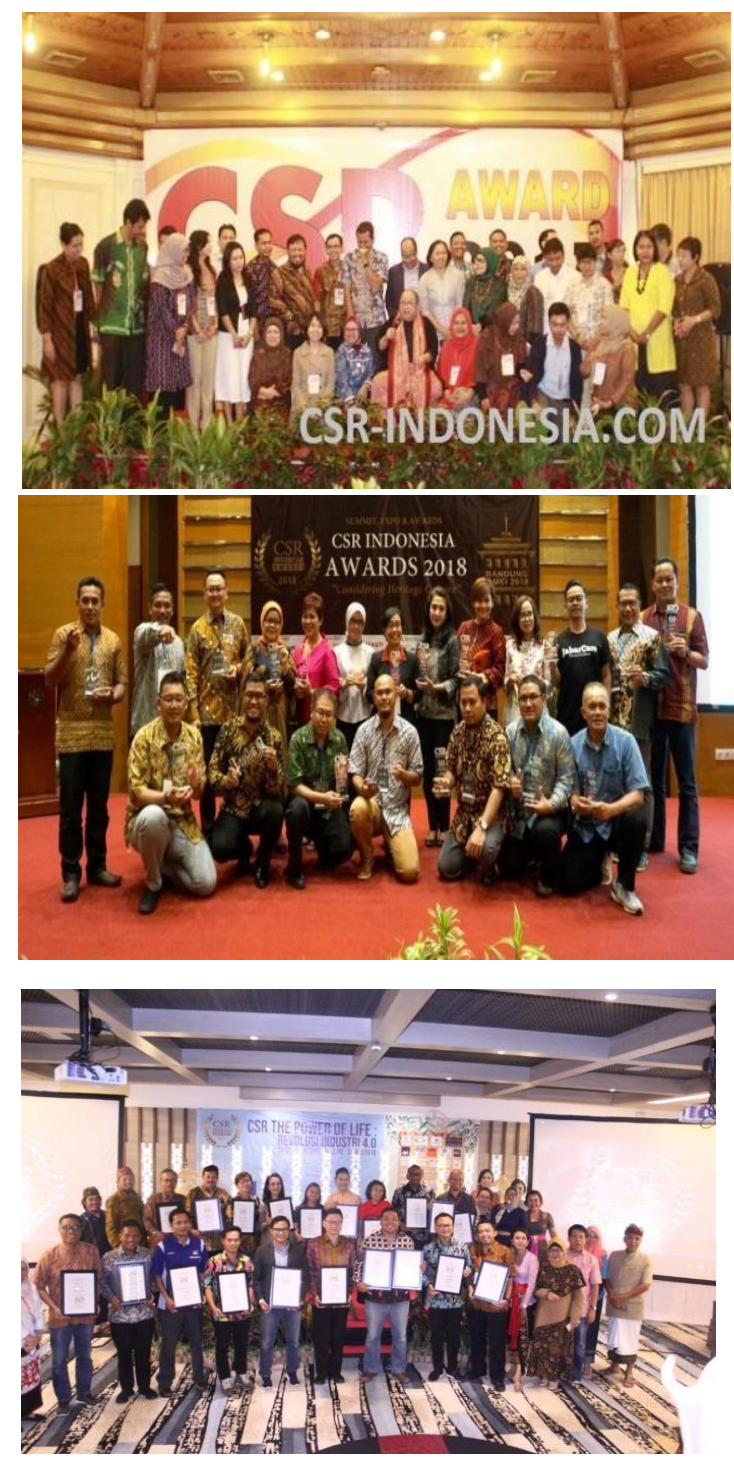

sumber : Dokumentasi Meprindo-Com, 2019

Based on the above problems, this study aims to find CSR communication models in facing the 4.0 industrial revolution and its implications for companies

\section{LITERATURE REVIEW}

\section{The Importance of Communication in Implementing CSR Programs}

Many companies care about meeting social responsibility expectations and communicating their company's corporate social responsibility policies (hereinafter referred to as CSR). In other words, CSR communication has become a vital problem in building and maintaining the legitimacy of a company in the 
eyes of stakeholders. According to the definition given by Podnar (2008: 75): "Cornelissen argues that CSR communication is now understood as a new sub-field in corporate communication (Cornelissen, 2011). The use of advertising, product labels, media relations, CSR reports and websites to achieve the above is done by companies. CSR reports and websites are considered smooth communication, while advertising and public relations are considered open communication, (Morsing and Schultz, 2006). The Web is considered a passive information tool (Pomering, 2011), obtaining information through the Web involves the active participation of users. Active user participation in the communication process is also considered a characteristic of the postmodern era, where communication is considered a process in which "meaning is produced through negotiation and conflict between writers, readers (recipients) and culture" (Firat and Dholakia, 2006: 146)."

The results of previous studies conducted by Ruliana and Marlinda, 2016) revealed that:

The CSR program has a positive ability to enhance the company's image and reputation when activities are carried out sustainably, well managed quantitatively, with internal and external orientation. CSR programs that are carried out continuously are one way to prevent a crisis from happening by raising the company's image in the view of its stakeholders. In CSR communication, it is important to distinguish between various potential communication strategies that consider the actual context and strategy of the company and which stakeholders are interested what kind of information. CSR should not be considered as an attachment to be added to an existing strategy from each company. From the perspective of corporate communication and reputation management, CSR must be integrated into the company's overall business strategy to become an inherent (and not artificial) part of the company (Cornelissen 2004). This means that CSR must be integrated from the inside out rather than vice versa. Only in this way will the company look consistent in its patterns of action (Morsing et al. 2008)

As for CSR communication itself, it is also important for companies to develop strategies that are appropriate to the needs of the company's interactions with stakeholders. Trading companies or companies that do not exhibit environmental damage do not engage in dialogue with environmental authorities and NGOs to the same degree as, for example, coal companies, but they can be suppliers or customers to the company. Such circumstances affect the extent to which companies must prioritize CSR descriptions on the website, in brochures, in reports, etc. The same applies to information about employee relations, employment agreements, local sponsors, etc. 
Companies are often better at communicating this. this type of information through media that is targeted directly at company employees and the local community rather than through media channels for consumers and society in general. Schultz et al. (2005) distinguish between direct and indirect communication when describing this problem. Direct communication is often arranged through external and formal channels such as reports, brochures, and websites, while indirect communication often occurs through channels other than external ones, for example, journalists in local daily newspapers and word of mouth from employees, consumers, and the local community. In terms of reputation, the value of Public Relations for using so-called third-party support is generally far greater than when the company itself is a more or less hidden message about CSR activities.

\section{CSR COMMUNICATIONS MODEL}

This research is based on the corporate communication model proposed by Nielsen \& Thomsen 2007 which previously used the discourse analysis approach later by Anne Ellreup Nielsen and Crista Thomson (2009) using the communication strategy approach, which is associated with corporate communication. In CSR communication, it is important to distinguish between various potential communication strategies that take into account both the context and the actual corporate strategy and the stakeholders interested in what type of information. CSR should not be considered as an attachment to be added to an existing strategy from each company. From the perspective of corporate telecommunications and reputation management, CSR must be integrated into the company's overall business strategy to become an inherent (and not artificial) part of the company (Cornelissen 2004). This means that CSR must be integrated from the inside out and not vice versa. Only in this way will the company look consistent in its patterns of action (Morsing et al. 2008). As for CSR communication itself, it is also important for companies to develop strategies that are appropriate to the needs of the company's interactions with its stakeholders. Trading companies or companies that do not exhibit environmental damage do not engage in dialogue with environmental authorities and NGOs at the same level as, for example, chemical companies, but they can be suppliers or customers of these companies. Such circumstances affect the extent to which companies must prioritize CSR descriptions on the website, in brochures, in reports, etc. The same applies to information about employee relations, work agreements, local sponsors, etc. The company will do better by communicating this. This type of information through the media is targeted directly at company employees and the local community rather than through media channels for consumers and society in general. Schultz et al. (2005) distinguish between direct and indirect communication when describing this problem. Direct communication is often arranged through external and formal channels such as reports, brochures, and 
websites, while indirect communication often occurs through channels other than external channels, for example reporters in local daily newspapers and word of mouth from employees, consumers, and the local community .

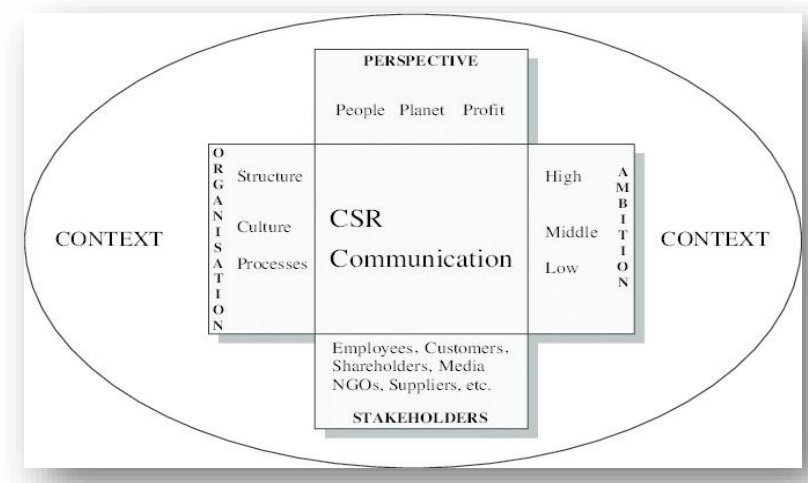

Sumber : Anne Ellreup Nielsen dan Crista Thomson (2009)

\section{CORPORATE SOCIAL RESPONSIBILITY (CSR)}

CSR is defined as a responsibility of large companies to the surrounding community and also as a form of participation of companies or organizations in efforts to overcome poverty hunger, reduce unemployment and benefits for education and the arts, Kast (2003: 212. The concept of CSR arises when the DEAF phenomenon arises among industrial societies, an acronym from: Dehumanism, Equalization, Aquariumization, and Femininezation (Ruliana. 2016). Industrial de-humanism, efficiency and a mechanism that is becoming stronger in the industrial world creates problems for humans.

Carroll presented its CSR model in 1991, which explained the history of CSR, where in the end Caroll described the SCR model which had four levels, namely; 1) Economic Responsibility - is the foundation on which everything is based. All organizations operate with the aim of producing morally, ethically and legally acceptable profits. 2) Legal Responsibility - is a modification of society about right and wrong. The company is required to play according to the rules of the game and comply with what is stated in the laws of the host country and follow all relevant rules and regulations set. 3). Ethical Responsibility Companies must do what is considered right and fair. 4). Philanthropic Responsibilities All companies must contribute resources to society and improve the quality of life of the people they connect with and act as good 
Carroll's CSR Pyramid-

The Four "Responsibilities"

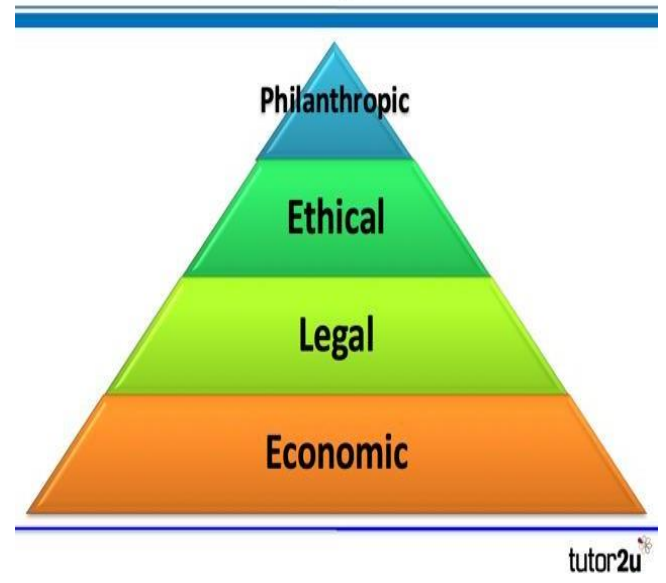

corporate citizens. If described Carrol's pyramid is as follows:

Sumber : https://www.tutor2u.net/business/reference/carrolls-csr-pyramid

This philanthropy is a form of corporate responsibility to the surrounding community by donating resources to the community and improving the quality of life of the people around or connected with them and acting as good corporate citizens Ernst and Young in a study, had conducted a survey that $94 \%$ of companies believe that social responsibility activities can have a positive impact on companies in doing business. However, in reality, companies that experienced significant changes after undergoing social responsibility activities strategically were only $11 \%$. However, in other findings in the research it was written, that CSR carried out and run by companies can increase the probability of people by $70 \%$ to buy or consume products and services sold by companies. Means that CSR if done correctly will produce positive results. The results of the feasibility study show that social responsibility is a way to maintain good relations between the company and the public, and must also be concerned about the balance of the surrounding environment, especially the community.

\section{INDUSTRY REVOLUTION 4.0}

The existence of the industrial revolution is also felt for the information media industry, from conventional to the latest trends. Newspapers, magazines, tabloids another print media are replaced by the more advanced and sophisticated world of the internet. Anyone can upload news into new news and a commodity where anyone can disseminate stories, news and posts that are personal with the purpose of showing off or just sharing information to be a new toy and an obligation for the current millineal community. This can be seen also from the holding of the CSR-Indonesia Awards which has been running three times using 
the sophistication of the internet. Moreover, supported by online media that can upload anything both news and promotions in it. For this reason, MEPRINDO Communication uploaded it on the website pages as stated below:
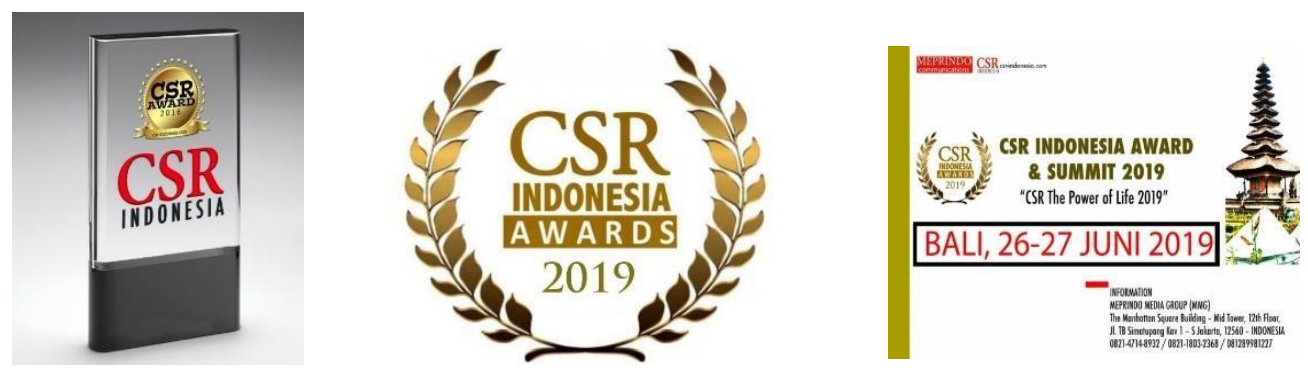

http://csr-indonesia.com/2017/01/20/csr-award-2016-csr-expo-summit-2017digelar-23-februari-2017/ http://csr-indonesia.com/2019/05/14/csrindonesiaawards-2019-digelar-30-31juli2019-bertempat-di-bali/

Aendra Medita, as chief executive and director of MePRindo, said,

"Implementation and participation of CSR-Awards every year has increased. Beginning in 2017 there were 10 companies that joined later in 2018 to 15 and in 2019 it increased again to become 30 companies. Participants who took part in the CSR-Indonesia Awards event were from various industries, rangin $g$ from banks, services, oil and gas, mining, insurance, power plants, and others scattered from various regions in Indonesia. The uniqueness of this event introduces the existing local culture (local wisdom). Through internet of things (IoT) technology plays an important role for communication in this era of industrial revolution, which makes it easy for MePRindo to interact and communicate with people around, companies, individuals, groups or anyone who is interested in getting info about Indonesia's CSR awards. "He explained

In this era of digitalization, it is marked by the entry of the internet which penetrates cyberspace without limits, forcing companies to face specific challenges related to technology, organization, and even ethics. The use of innovative "tools" associated with the revolution not only brings new technological challenges, opportunities to build new competitive advantages, new fields and types of business utilization but there are also doubts, questions, or even pathologies and paradoxes. Sometimes, entities that do not fully understand the essence of new concepts, methods, or techniques use them incorrectly. The 
existence of sophisticated technology is already where the automation trends and the exchange of data, which includes cyber-physical systems and the internet of things (IoT), and cognitive computing, cloud computing. This trend has changed many human lives from various lines. This 4.0 Revolution has instilled intelligent technology that can be connected with various fields of human life.

In the first approach, the level of interactivity is low, and Internet usage is unidirectional; because the main goal is to spread information and try to improve the company's image in business. However, in the second approach, the level of interactivity is high, and the Internet is used to facilitate two-way communication and to maintain relationships by enabling dialogue and interaction between the organization and its stakeholders. Interactive communication is one of the most important information channels for companies because of changes in social dynamics (Fieseler \& Fleck, 2013; O'Reilly, 2005; 2006).

The industrial revolution 4.0 brought many changes with all the consequences, the industry will be more compact and efficient. At the beginning of the Industrial Revolution 1.0, he 18th century, the growth of mechanization and energy based on steam and water power became a marker. The era of the Industrial revolution 2.0 changes marked by the development of electrical energy and the driving motor. However, the era was soon eroded with a fairly rapid change in the 3.0 Industrial Revolution, marked by the growth of electronicsbased industries, information technology, and automation. The presence of such a rapid Industrial Revolution 4.0 is marked by the development of the Internet of or for Things (IoT), which presents new businesses, new jobs, new professions that were unthinkable before. Internet of things (IoT) technology plays an important role for communication in this era of industrial revolution, which makes it easy for MEPRINDO to interact with stakeholders.

\section{AWARDS}

Awards are a form of appreciation or something given to individuals or groups if they do an excellence in a particular field. The awards given can take the form of medals, trophies, titles, certificates, plaques, badges, pins or ribbons. Prizes are usually given to award recipients, they can be in various forms with certificates, money, nobel gifts for contributions to the community, and pulitzer prizes for literary awards or achievements. Awards can also be in the form of gifts without prizes for achievements.

Likewise with what was carried out by the organizers in the implementation of the CSR Indonesia Awards, MePRindo chose how to use digital media and the internet to inform the company / stakeholder messages in both the private and government sectors. The term CSR has only been used since the 1970s and is increasingly popular, especially after the presence of Cannibals With Forks: The Triple Bottom Line in 21st Century Business (1998), by John Elkington. In its development in Indonesia, based on the Law on Regulations 
concerning CSR regulated in the Limited Liability Company Law no. 40 Article 74 of 2007, the government requires companies and corporations to carry out CSR.

\section{RESEARCH METHODS}

This research uses a qualitative approach with descriptive methods. Data collection uses the observation method, which is observing the activities of the Mepromdo Communication company in planning and implementing CSR Award programs in the face of the 4.0 revolution. The documentation study was carried out on the Meprindo- Communications company's Strategic Plan document in carrying out the CSR Award in the face of the industrial revolution 4.0 and literature study. Key informants in this study were the director of Meprindocommunication and the Manager of Meprindo Communicatinn. while the informants in this study were the Mifa Brothers company represented by Azizon Nurza and CSR-Indonesia figure Frans Bambang Siswanto (Deceased)

Literature analysis or literature study is used as a data collection technique. This method according to Diana Ridley (2012) is a way to identify theories and previous research that already exist, which can influence the choice of research topics and methods to be used. The data source is in the form of scientific studies that have been studied previously, namely corporate communication books, CSR books, communication journals that are relevant to research, relevant bulletins, and reports on company activities. These reports are related to the internet about the corporate communication model in the face of the industrial revolution era 4.0. Data analysis techniques used in this study include data collection activities, data reduction, data display, and conclusion drawing or conclusion / verification

\section{RESULTS AND DISCUSSION}

In discussing this research, the key informants in the study were the Director of Meprindo, the informants in this study were two people, the Mifa Brothers and Lahai Coal. From observations obtained from Medita, the director and chief executive of MePRindo (7/29/19) said that:

"companies that have participated in the CSR Indonesia Awards event in 2019 totaled 30 participants, namely; PT. Adaro, PT. Pupuk Kaltim, Adaro, PT. Lahai Coal, Akzonobel, Axa Indonesia, PT. Asmin Bara Beronang, PT. Bara Energy Lestari, PT. AginCourt Resources, PT. Kalimantan Prima Persada, PT Modernland, PT Cisco, PT. Mifa Brothers, PT. BPWC-Cirata, PT ASDP-Indonesia," 
Further explained that

There are 10 categories of Awards namely; Cipta Karsa Mandiri: CSR field that provides creative works for the community and also the public or the community independently. 2). Reka Karsa Lingkungan: The social CSR sector provides assistance to an area or community on a regular basis and is helped so as to be able to make useful initiatives in the surrounding area. 3). Bangun Karsa Rupa Social: The CSR sector contributes to a disaster event for the community. 4). Primary Didaktika Excellent: is the field of CSR that provides assistance or direct assistance to the community in the field of education. 5.) Karsa Budaya Prima: CSR cultural sector provides conservation or conservation support. 6) Cipta Utati for One: Health CSR sector that provides support or means of nutritional health and also a healthy way of life. healthy7). Gagas Inova Karya: The CSR field that supports innovators in realizing new and original works8). Gerak Mandiri Siaga: Actor who provides immediate assistance to the community quickly. 9). Primary Sports Power: The field of sports CSR that fosters future athletes. 10). Insan Gagas brilliant: Given to individuals who have carried out brilliant ideas and are useful for the nation and society."

In this study, researchers applied CSR communication models from Anne Ellreup Nielsen and Crista Thomson (2009) which consisted of Contex which included source, structure and culture, 3P perspective (Planet, People and Profit), CSR Communication, high, middle, low is the dimension of ambition to be achieved and the goal are stakeholders based on the communication strategy carried out by Meprindo. Still according to Medita, stated:

"CSR was born because of the emergence of concern for the surrounding community that grows among companies in accordance with government regulation no. 40 of 1974, but there are still many companies that have not been moved to do CSR. The need for parameters to oversee and provide stimulus is also basic knowledge that it is important for companies to do CSR. MePRindo Communication also has a goal by holding this CSRIndonesia Awards, it is hoped that other companies will be moved to carry out CSR in a sustainable manner. "

It can be said that the idea of the birth of the implementation of the CSR Award program is to facilitate companies engaged in products and services that can be valued in terms of CSR activities that are based on government regulations 
and must be implemented by all companies, and through CSR events companies can measure the level of success in implementing CSR programs when getting awards.

\section{$3 P$ Perspective (Profit Planet People)}

Companies that carry out CSR should pay attention to the perspective / perspective for CSR management for the sustainability of the program, as said by a CSR expert, Frans Bambang Siswanto, at the opening of the CSR Awards in Bali, (30 July 2019). One week after opening the CSR Indonesia Awards event in Bali, Frans said;

" The company must prepare the company's basic foundation with a

"Triple Bottom Line" (profit, peope and planet) .1. Profit - also called company profit. If there is no profit then People \& Planet will not be able to do. Profit is a key element that can bridge a business and people \& planet. 2. Planet - is associated with climate change (global warming), illegal logging, overfishing, and often issues that occur around and become the negligence of people (humans) on this planet to protect the environment as a sustainable business. 3. People - in this case human beings on the planet to be able to contribute their energy and thoughts to humanity and are efficient for the company and surrounding communities. That is, the focus is on people, not the company building, not merely profits, or anything else."

Frans also added;

"The concept of Tri Bottom Line that must be added is spirit. The spirit that is meant here is the spirit of helping that is based on God the One Helping others will not impoverish their helper but instead will provide extraordinary blessing."

\section{CONTEXT (ORGANIZATION)}

In organizing the CSR Award, MePRindo considers the context of communication related to the number of communication participation based on social and cultural characteristics as well as the time factor that determines the success and smoothness of the CSR Award, while the communication carried out in the implementation of the CSR Award is mass communication and interpersonal communication. Mass communication is used because we are facing what is called the era of the industrial revolution 4.0 because it is related to digitalization in relation to this matter, Aendra argues that;

"Mass communication, including the media, has developed rapidly and can be used as a tool to provide information to the public so 
that it can influence the public in thinking, behaving and behaving in making a decision to take part in the CSR Indonesia Awards associated with Industry 4.0 revolution which provides solutions for everyone to be able to communicate easily and quickly, so that any message delivered can be received properly and vice versa. The development of science and technology requires everyone to continue learning especially now that it has entered the era of digitalization 4.0. Therefore digital media in the industry 4.0 era is the right strategy to be able to send messages and be quick to receive feedback again. "

What is revealed by Medita is an interactive communication in which the recipient of the message will also be able to later become a message, resulting in feedback (feedback), which aims to enhance the company's reputation and positive image. Because with the news and various reviews in the media both in print, electronic and digital media will provide positive benefits for the company. So the media used as a tool to promote CSR Awards relates to the context of communication, namely the number of communication participants involved that are heterogeneous which is very much determined by the aspects of geography, psychography and demography. Interpersonal communication is used to see the feedback from the target audience as feedback from the promotion carried out.

\section{Culture}

Cultural factors are also used as a consideration in carrying out CSR Awards because culture in CSR activities is related to the corporate environment where CSR communication occurs as stated by Medita, as follows:

"Community culture has different characteristics, and companies

that carry out CSR activities also consider this in carrying out their

activities. One of the factors that we value is the local wisdom of

the surrounding community, which has its own characteristics and

of course the sustainability of the programs implemented."

The statement above reflects that the CSR activities carried out by MePRindo pay close attention to and consider that culture plays an important role in the company to determine the implementation of programs carried out in accordance with the culture of the local community (community). According to Devito in his book Human Communication (1996: 481). 'The way we communicate is largely influenced by culture, people from different cultures will communicate differently. We need to pay special attention to avoiding cultural differences that hold meaningful interactions, but instead become a source to enrich our communication experience. If we want to communicate effectively, we need to understand and appreciate these differences. We also need to understand the common obstacles and principles of effectiveness for communicating between 
different cultures as revealed by Sri (LahaiCoal):

"We build communication with the surrounding community by studying their culture, so that we can enter into it so that the ways we communicate, the conditions of our communication, the language and style of language used and our nonverbal behaviors, all of which are primarily a response to and the function of our culture."

Communication is bound by culture. As culture differs from one another. Then the practice and communication behavior of individuals who are cared for in these cultures will also be different. Culture is a whole pattern of life. Culture is complex, abstract and broad. Many aspects of culture also determine the behavior of human social activities

\section{Structure}

MePrindo's organizational structure is held by four people who invest shares, therefore the highest decision is at the members' meeting, there is a board of commissioners and a board of directors (board of directors) in charge of 1) Business Director to carry out Events, CSR and Advertising, and 2) Editorial Director ( Editor and Chief), each director has the same position and authority. under both of them there are managers who will manage marketing and marketing, Public Relations, Editorial Board, and IT (Information and Technology) Financial Managers only dealing with directors, editorial boards and members' meetings as the highest dicision maker. If the chart is drawn as shown below: 


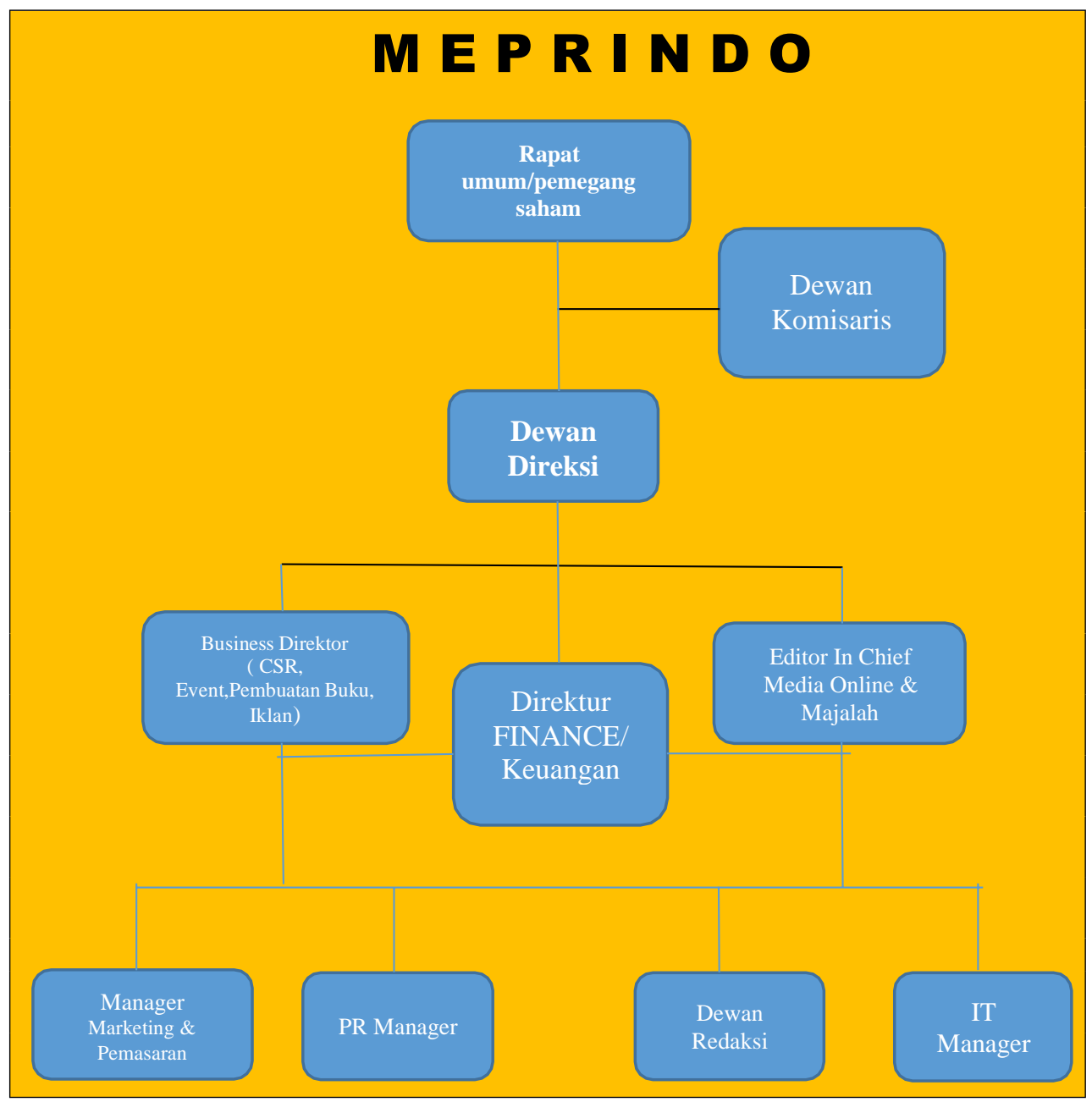

\section{COMMUNICATION PROCESS}

In the process of implementing the CSR Indonesia Awards, MePRindo provided information / messages on the CSR-Indonesia Awards event through digital media and the internet as said by Medita;

"To inform the existence of the CSR-Indonesia Awards event, MePRindo uses digital media (internet) from Whatsap, email, Instagram, and the website, which is welcomed and positive. On the occasion before the opening ceremony of CSR Indonesia Awads, in Bali (July 28, 2019. They thought the industry 4.0 era and digitalization, this made it easier for everyone to be able to communicate easily and quickly, so that any message delivered could be well received and vice versa. The existence of media Digital in the 4.0 industry era is the right strategy to be able to send messages quickly and immediately receive feedback 
again.The existence of the CSR Indonesia Awards is to raise the company's reputation and positive image."

The results of research conducted by Andrini, (2018) stated that: From the interview information obtained from Sri (Lahai Coal), at the holding of the CSR Indonesia Awards (7/30/19):

"We get information about CSR-Indonesia Awards from the web, social media and the internet. We need to take part in this activity to measure the level of success in carrying out CSR and feedback to get an Award, which will raise the company's reputation and positive image."

\section{Ambition}

Ambition in the big dictionary wants (desire, desire) to become (get, achieve) something (such as rank, position) or do something. In this case MePRIndo has the ambition to conduct this event to give awards to companies that have carried out CSR in addition to gaining a more positive reputation and image to the company. The concept of Botton of line can be accepted here, because it relates to MePRindo's perspective / perspective in conducting assessment criteria for companies that have carried out CSR. CSR Awards also serve as a batik for companies to carry out CSR, as well as of course providing knowledge and knowledge sharing for fellow participants in particular and the wider community in general. The amount of ambition is influenced by the things that have been written above, so MePrindo took steps to conduct the CSR Indonesia Awards event based on a very high desire.

"Information about CSR Awards is obtained from social media, email and whatsapp. All communications are carried out through social media and the internet, which often gets feedback from us. Conventional methods have been abandoned that move to industry 4.0."

At the beginning of the implementation of the CSR-Indonesia Awards, the promotion carried out by MePRindo in addition to giving fliers or brochures to clients, and by conventional means (postal mail) but also through the internet and social media. However, messages conveyed through social media and the internet are more effectively received by clients than conventional methods. The message received by the filtered stakeholder (stakeholder) which then receives responses in the form of questions, suggestions and others, so that the message is interregnated via messages via the internet and social media to the communicator, then the communicator accepts to be interpolated communicate in a circular manner and get feedback from the development of communication models Anne Ellreup Nielsen and Crista Thomson 


\section{STAKEHOLDERS}

Stakeholders according to Anne Ellreup Nielsen and Crista Thomson (2009) include workers, employees, media, NGOs, suppliers, etc. So it can be said that included in the stakeholders are all parties in the community, be it individuals, communities or community groups, who have a relationship and interest in a company / organization / company (stakeholders or interested parties. Sri from Lahai Coal on (7/30/19) stated that;

"In carrying out the CSR program so that everything runs smoothly, Lahai Coal approached community leaders with the aim of making it easier for them to do CSR because a community leader is considered a 'magic person' where all his words are heard which are the aspirations of the community. Within the company itself there is also a manager who will arrange his employees to work together with community groups to carry out CSR. Managers have a responsibility in making decisions and their implementation."

Azizon (MIFA Brothers) also added;

"In carrying out this CSR, our company always pays attention to the policies of the government and follows ISO 26000. If CSR is carried out in the regions or districts, it must pay attention to and refer to government regulations made by the regencies or agencies that are under it or those under it "

According to Anne Ellreup Nielsen and Crista Thomson (2009), the description or parts of these stakeholders each have their own role, for example in the stakehorder there is an owner / investor as a capital holder who also has a role to oversee the company and observe the performance of the stakeholders. employees and also the financial condition in the company. Employees / employees play a direct role in the process of carrying out CSR activities. Suppliers also have a role in providing raw materials that will be used to carry out CSR where as consumers are people or people and the environment is given CSR assistance.

According to Harmoni1, Ratih and Purwanti in their national paper system 2013 information said,

"Communication The concept of stakeholders is defined as any group or individual that can influence or be affected by the achievement of company goals. Stakeholders have the right to specific information for certain decisions and relevant information must be provided including the information environment. Stakeholders have the ability to control or influence company resources. The concept of stakeholders can be used to personalize social responsibility by assigning specific groups or people to consider. CSR then becomes a matter of identifying, managing, communicating with and / or entering into dialogue with relevant 
stakeholders. The challenge lies in being responsive and balancing the multiplicity of certain interests. Recently, with the advent of social media and the internet, companies have begun to utilize web-based technology as a means of reporting to external stakeholders."

So in considering the use of a stakeholder's website. The company acts as a communication medium, a clear potential with its advantages compared to conventional communication, that websites, social media and the internet as direct communication media, can provide real-time data and instant information.

Based on the description above, then the CSR communication process can be portrayed by Meprindo to Stakeholders to convey messages or information about the implementation of CSR Awards. The communication model is as follows:

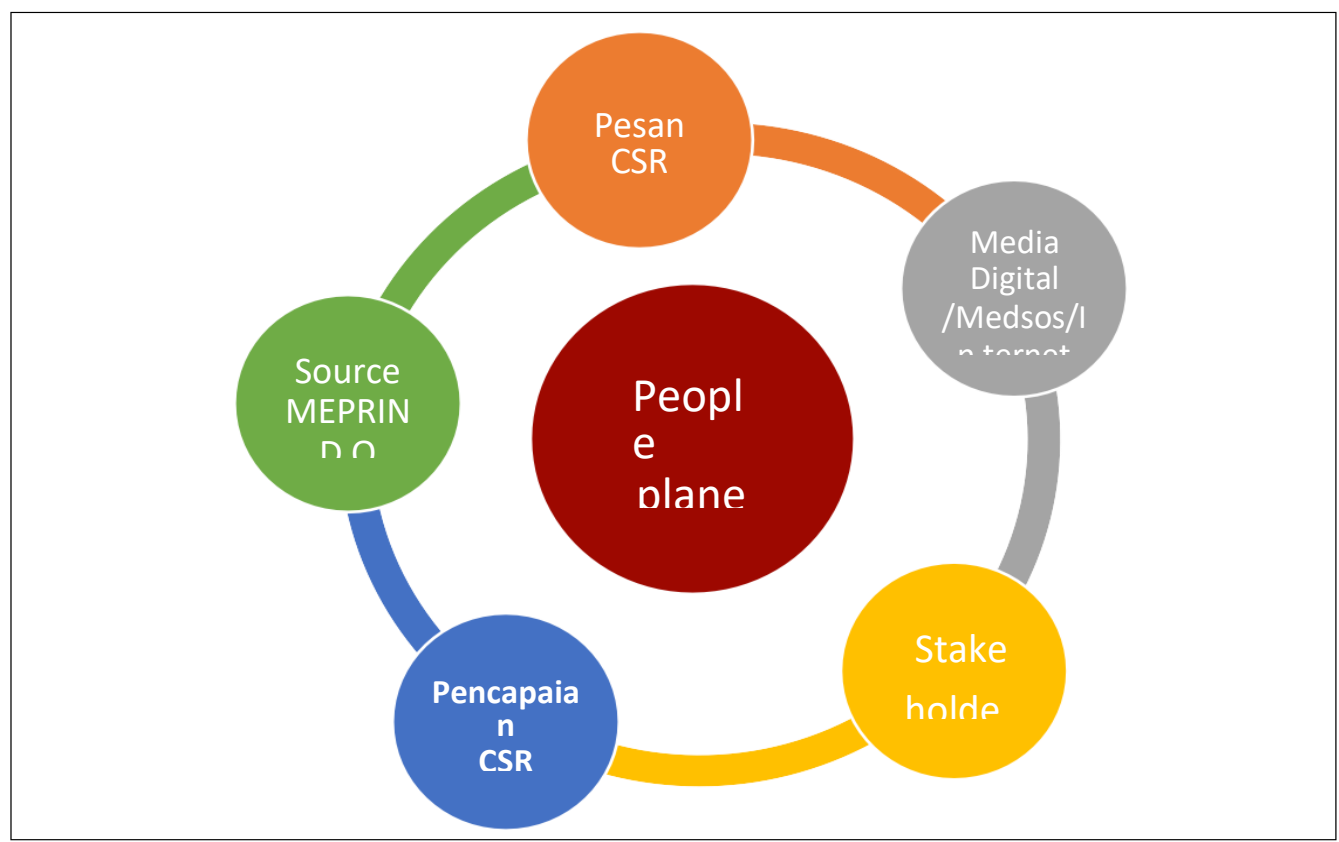

The Context of CSR Communication Towards the Industrial Revolution 4.0 :

This communication model Meprindo as a source and communicator gives messages about CSR-Indonesia Awards, to clients by using social media such as WhatsApp, Instagram, Facebook and email using the internet in the Industry 4.0 era, messages are received by the communicant / client (stakeholder) and exert an effect positive and obtained the CSR-Indonesia Awards. The presence of MePRIndo, which has held the CSR Indonesia Awards event, gives a new color to the CSR world to compete in doing the best possible sustainable CSR (suistanaible), so that the criteria for judging CSR are met. In informing the existence of this CSR activity MePRindo always promotes it either through writing / words, pictures / advertisements entirely through social media such as 
Facebook, email, website, Instagram, and WhatsApp is an effective message to be conveyed to stakeholders in this digital era. The message is received by the client and gives feedback back by responding to the message received to then send the message back with a variety of questions or just suggestions and so on through communication with social media and digital media, so there is mutual communication that is mutual understanding (Ruliana, 2016) between the two parties in enhancing the company's image and reputation as well as a place to share knowledge and technology, it is already the extent to which these companies use technological sophistication in the implementation of CSR in the digitalization era in the face of the Industrial Revolution 4.0

\section{CONCLUSION}

The implementation of CSR award communication initiated by MePRindo is based on the organization's internal conditions by considering the structure, culture and processes in the context of the industrial revolution 4.0. The message delivered in the implementation of CSR is informative and persuasive using digital media or social media aimed at stakeholders, namely companies, employees, participants and NGOs. The basis of CSR implementation refers to 3P (Three Botton Line - people, Planet and Profit) which must be instilled by companies as CSR Award participants so that they can show the work or performance of the company. As an effect of these activities, the participants rated it positively because it could enhance the reputation and image of the company, while as feedback they received the CSR Indonesia Awards from MePRindo 


\section{REFERENCES}

ANDI. Yogyakarta. Panggabean, M.F. 2009. Pengaruh Kegiatan Filantropi Perusahaan Terhadap Citra CSR Awards Komunikasi Antar Budaya Komunikasi Interstudi

Bentuk Penyelenggaraan CSR AWARDS

FUNGSI Ekonomi, Sosial, Budaya, Pemberdayaan MAKNA Memberikan Citra Positif untuk Perusahaan,

Bertens, K. (2004), Etika. Jakarta : Gramedia Pustaka Utama.

Budimanta, Rudito. 2004. Corporate Social Responsibility: Jawaban Bagi Model Pembangunan Indonesia Masa Kini. Jakarta

Choi, Frederick D.S., and Gerhard D. Mueller, 2005., Akuntansi Internasional Buku 1, Edisi 5., Salemba Empat, Jakarta

Cornelissen, J. (2011). Corporate Communication: A Guide to Theory and Practice (3rd ed., p. 272). London: Sage.

Jamiluddin. -----. Riset Kehumasan. Jakarta: PT. Grasindo. Roslina. 2010. Citra Merek: Dimensi, Proses Pengembangan serta Pengukurannya. Dalam Jurnal Bisnis \& Manajemen vol.6 no.3, Mei 2010.

Kast FE, Rosenzweig JF, 2003. Organisasi dan Manajemen. Edisi Keempat, Alih Bahasa: A. Hasymi Ali. Jakarta: Bumi Aksara.

Moenir, H.A.S., 2001, Manajemen Pelayanan Untuk di Indonesia, Bina Aksara, Jakarta.

Mulyadi. 2003. Pengelolaan Program Corporate Social Responsibility: Pendekatan, Keberpihakan dan Keberlanjutan. Materi Seminar. PSKK, Jogjakarta.

Nugroho, B.A. 2005. Memilih Metode Statistik Penelitian dengan SPSS. Penerbit Prasetya, F.E. 2010. Analisis Pengaruh Corporate Social Responsibility "Lifebuoy Berbagi Sehat" Terhadap Loyalitas Konsumen dan Citra Perusahaan

Rahman, Reza. 2009. Corporate Social Responsibility: Antara Teori dan Kenyataan. Yogyakarta : Media Presindo.

Rakhmat, J. 2000. Metode Penelitian Komunikasi. Rosdakarya. Bandung Ritonga, Rudito, Bambang\& Budimanta, Arif \& Prasetijo, Adi (2004). Corporate Social Responsibility: Jawaban Bagi Modal Pembangunan Indonesia Masa Kini. Jakarta: ICSD

Seravina, M. 2008. Pengaruh Penerapan Corporate Social Responsibility (CSR) Terhadap Loyalitas Nasabah Tabungan Britama (Studi Kasus Pada Nasabah PT.Bank Rakyat Indonesia (Persero) Tbk. Cabang Bogor).

Suharto, Edi (2007), Pekerjaan Sosial di Dunia Industri: Memperkuat Tanggung jawab Sosial Perusahaan (Corporate Social Rensposibility), Bandung: RefikaAditama Susiloadi, P. 2008. "Implementasi Corporate Social Responsibility untuk Mendukung Pembangunan Berkelanjutan”, Spirit Publik, Vol 4, No. 2, pp. 123-130. Wibisono, 
Y. 2007. Membedah Konsep dan Aplikasi CSR (Corporate Social Responsibility). Gresik: Fascho Publishing.

http://www.psychologymania.com/2012/11/pengertian-corporate-social.html http://id.shvoong.com/social-sciences/economics/2283794-sejarah-danerkembangan- corporate-social/\#ixzz2NLe1hARz update 12 Januari http://mamrh.wordpress.com/2008/07/21/53/

http://www.csr-indonesia.com

\section{Journal}

Andrini, Susi (2018), Peran CSR dalam Komunikasi Antar Budaya, Jurnal Inter Komunika, Vol 3 No.1, Sekolah Tinggi Ilmu Komunikasi, Inter Studi, Jakarta

R. 2018. Karakteristik Model dan Analisa Peluang-Tantangan Industri 4.0. Jurnal Teknik Informatika Politeknik Hasnur. Volume 4, No. 1. PHASTI.

Fikret-Pasa, S., Kabasakal, H., \& Bodur, M. 2001. Society, Organisations, and Leadership in Turkey. Applied Psychology: An International Review, 50(4): 559-589

Mitra Nayan, Asif Akhtar2 and Ananda Das Gupta3 2018. Communicating Corporate Social. Responsibility in the post mandate period: Evidence from India. Mitra et

al. International Journal of Corporate Social Responsibilityn(2018) 3:10 https://doi.org/10.1186/s40991-018-0033-4

Podnar, K. (2008) "Guest editorial: communicating corporate social responsibility", Journal of Marketing Communications, 14(2), 7581. Podnar, K. (2008) "Guest editorial: communicating corporate social responsibility", Journal of Marketing Communications, 14(2), 75-81.

Pomering, A. (2011) "Communicating corporate social responsibility through corporate image advertising" in Ihlen, Bartlett, J. and May, S. (eds) Handbook of Communication and Corporate Social Responsibility, Malden, MA: Wiley- Blackwell, 379-398. Pomering, A. (2011) "Communicating corporate social responsibility through corporate image advertising" in Ihlen, Bartlett, J. and May, S. (eds) Handbook of Communication and Corporate Social Responsibility, Malden, MA: Wiley-Blackwell, 379-398.

Proceeding International Conference on Ethics in Governance (ICONEG 2016) Ruliana, Popppy \& Marlinda Irwanti, 2016. Social Responsibility and

Corporate Communication. Advances Corporate in Social Science, Education and Humanities Research, volume 84 Atlantis Press

https://www.atlantis-press.com/proceedings/iconeg-16/25874205 